\title{
COAGULANT-FLOCCULANT FROM SECONDARY RESOURCES FOR TREATMENT OF INDUSTRIAL AND MUNICIPAL WASTEWATER
}

\author{
V. A. Shablovski ${ }^{1}$, A. V. Tuchkoskaya ${ }^{1}$, V. A. Rukhlya ${ }^{1}$, O. G. Pap ${ }^{1}$ \\ ${ }^{1}$ Research Institute for Physical Chemical Problems of the Belarusian State University, \\ 14 Leningradskaya st, 220006 Minsk, Belarus, email: shablovski@bsu.by
}

DOI: https://doi.org/10.20535/2218-930022021240165

Coagulants and flocculants are used almost at all drinking water supply facilities, wastewater treatment plants of municipal and industrial enterprises in Belarus and Ukraine to intensify and increase the efficiency of the processes of purification, clarification and discoloration of water and wastewater. Mainly as coagulants aluminum and iron salts are used, as flocculants - active silicic acid, starch, cellulose derivatives, polyacryloamide, etc.

Sulfuric acid treatment of alumina-containing raw materials allows, in the course of one process, to obtain a mixture of active substances - salts of aluminum, iron, active $\mathrm{SiO}_{2}$. In this case, there is no need to separate the salt from suspended particles and colloidal silicic acid. The presence of suspended dispersed particles in the active substance, as well as colloidal silicic acid and its salts, enhances and accelerates coagulation. The resulting solution, along with aluminum sulfate, contains silicic acid, which acts as a flocculant in the process of water purification. In addition, the processed products also contain ferrous sulfate, in the presence of which a better coagulation result is achieved.

Industrial tests of the coagulant-flocculant were carried out in order to purify wastewater from oil products. The test results showed that the effectiveness of the coagulant-flocculant in reducing the content of oil products in wastewater is comparable to the currently used aluminum sulfate.

The effectiveness of the developed coagulant-flocculant for the purification of drinking water was evaluated in comparative tests with a coagulant "Polvak-68" in the mode of trial coagulation on a laboratory flocculator. The research results are showed that the value of all parameters characterizing the contamination of the source water are highty decreasing for experimental coagulant-flocculant in compare with regular product.

Keywords: coagulant, flocculant, aluminum, wastewater, drinking water

Received: 15 September $2021 \quad$ Revised: 18 September $2021 \quad$ Accepted: 30 September 2021

\section{Introduction}

Coagulants and flocculants are used almost at all drinking water supply facilities, wastewater treatment plants of municipal and industrial enterprises in Belarus and Ukraine to intensify and increase the efficiency of the processes of purification, clarification and discoloration of water and wastewater [Zapolskyi, 1987, Kulskyi 1982]. Mainly as coagulants aluminum and iron salts are used, as flocculants - active silicic acid, starch, cellulose derivatives, polyacryloamide, etc., which are imported into the republic from 
countries of near and far abroad. The demand for coagulants and flocculants is estimated at tens of thousands of tons. The bulk of aluminum salts used as coagulants are produced in the world with acidic dissolution of scarce and expensive aluminum hydroxide.

In the conditions of Belarus and Ukraine, the most rational is the production of aluminum coagulants and flocculants based on active silicic acid by acid leaching of common raw materials - clays, kaolins, nepheline [Lainer, 1982, Veliaev, 2011], etc., as well as from secondary resources located on the territory of these countries, containing aluminum and silicon.

A promising conception to solve this problem is the use of secondary raw materials of industrial enterprises, which are waste solutions of mineral acids in the amount of hundreds of tons per year. Currently, these solutions are neutralized with soda ash and discharged into the sewer. This is a very costly process that puts additional stress on the ecosystem.

The aim of this work was to study the possibility of obtaining a coagulant-flocculant with specified technical parameters based on sulfuric acid effluents of OAO PolotskSteklovolokno and OAO Minsk Tractor Plant, as well as conducting tests in specific technological modes for water purification.

\section{Materials and Methods}

Sulfuric acid treatment of aluminacontaining raw materials allows, in the course of one process, to obtain a mixture of active substances - salts of aluminum, iron, active $\mathrm{SiO}_{2}$. In this case, there is no need to separate the salt from suspended particles and colloidal silicic acid. The presence of suspended dispersed particles in the active substance, as well as colloidal silicic acid and its salts, enhances and accelerates coagulation.

We have developed a method for producing a coagulant-flocculant, which includes the following technological stages. The nepheline concentrate was treated with an aqueous solution of sulfuric acid of $10-15 \%$ concentration at room temperature for 20 minutes. Sulfuric acid solutions were secondary raw materials produced by OAO "Polotsk-steklovolokno" and were obtained after washing the glass fiber from ions of alkali and alkaline earth metals. After the process of sulfuric acid treatment, a reaction mass was obtained, from which, after settling for 5-10 minutes, a coarse-grained precipitate was separated. The suspension over the sediment was decanted and used for water purification as a coagulant-flocculant. The suspension contained: $\mathrm{Al}_{2} \mathrm{O}_{3}-24 \mathrm{~g} / \mathrm{l}, \mathrm{SiO}_{2}$ $41.2 \mathrm{~g} / \mathrm{l}$, solid suspended matter - $24.3 \mathrm{~g} / \mathrm{l}$. Since the resulting suspension tend to gelatinize after 7 hours, stabilizers were added to its composition for longer storage polyacrylamide or hydrolyzed polyacrylonitrile. During the experiment, it was found that the introduction of such stabilizers at a concentration of 0.005-0.01\% is an effective method of preventing the gelation of the resulting coagulantsflocculants.

The resulting solution, along with aluminum sulfate, contains silicic acid, which acts as a flocculant in the process of water purification. In addition, the processed products also contain ferrous sulfate, in the presence of which a better coagulation result is achieved. 


\section{Results and Discussion}

A pilot batch of coagulant-flocculant was tested at the sewage treatment plant of OAO "Zhilkommuslugi-Svisloch". The results are presented in Table 1 . The results of the analysis of samples taken before and after the treatment of wastewater with the reagent indicate a significant decrease (by 53-91\%) in the main indicators characterizing polluted water. The most effective is removal of phosphates. The nitrogen content was decreased by more than half. A decrease in the content of suspended solids (by $88.4 \%$ ) is practically ensured at the first stage of treatment (radial settling tank).

Table 1. Results of analysis of wastewater samples

\begin{tabular}{|l|c|c|c|c|c|}
\hline \multirow{2}{*}{ Place of sampling } & \multicolumn{5}{|c|}{ Indicators, mg/l } \\
\cline { 2 - 6 } & $\begin{array}{c}\text { Suspended } \\
\text { matter }\end{array}$ & BOD5 & Nitrogen & $\begin{array}{c}\text { Phos- } \\
\text { phorus }\end{array}$ & Iron \\
\hline Inlet chamber & 133.5 & 106 & 34 & 14 & 2.36 \\
\hline Grit catcher & 103 & 70 & 25 & 6 & 1.64 \\
\hline Radial settling tank & 15.5 & 33 & 16 & 1.25 & 1.08 \\
\hline \% of purification & 88.4 & 68.9 & 52.9 & 91 & 54.2 \\
\hline Regulations (after two filter stages) & 15 & 11 & 6.5 & 0.2 & 0.43 \\
\hline Standard & 0.75 to & 6.0 & Tot. 13 & 3.5 & 0.3 \\
\hline
\end{tabular}

Industrial tests of the coagulant-flocculant were carried out at the "Flotation" unit of OAO "Naftan" in order to purify wastewater from oil products. A pilot batch of coagulantflocculant was made from nepheline and waste sulfuric acid, which, according to the technological process, should be neutralized and discharged into the sewage system. The content of aluminum sulfate in the obtained coagulant-flocculant was $0.6 \%$, the content of active silicic acid was $3.4 \%$. The test results presented in Table 2 showed that the effectiveness of the coagulant-flocculant in reducing the content of oil products in wastewater is comparable to the currently used aluminum sulfate.
The effectiveness of the developed coagulant-flocculant for the purification of drinking water was evaluated in comparative tests with a coagulant "Polvak-68" in the mode of trial coagulation on a laboratory flocculator. The test results are shown in Table 3.

On the basis of the department of technological systems of water supply and water treatment of RUP "Zhilkommuntekhnika", laboratory tests of the coagulant-flocculant were carried out in order to assess the effectiveness of purification of the source water of the treatment plant of the UP "Minskvodokanal". 
Table 2. The results of industrial tests of the coagulant-flocculant in the production conditions of OAO "Naftan"

\begin{tabular}{|c|c|c|c|c|c|}
\hline $\begin{array}{c}\text { Amount of } \\
\text { coagulant, } \mathrm{m}^{3} / \mathrm{h}\end{array}$ & $\begin{array}{c}\mathrm{pH} \\
\text { inlet. }\end{array}$ & $\mathrm{pH}$ outlet & $\begin{array}{c}\text { Oil products } \\
\text { inlet. }\end{array}$ & $\begin{array}{c}\text { Oil products } \\
\text { outlet. }\end{array}$ & $\begin{array}{c}\text { Decrease of oil } \\
\text { products content, } \%\end{array}$ \\
\hline \multicolumn{6}{|c|}{ Aluminum sulfate } \\
\hline 0.9 & 7.36 & 6.71 & 64.4 & 26.5 & 58.9 \\
\hline 1.1 & 7.36 & 7.06 & 57.4 & 27.4 & 52.2 \\
\hline \multicolumn{7}{|c|}{ Coagulant-flocculant } \\
\hline 0.9 & 7.34 & 6.96 & 64.4 & 21.6 & 66.5 \\
\hline 1.2 & 7.74 & 6.96 & 57.4 & 27.1 & 52.8 \\
\hline 1.1 & 7.74 & 7.00 & 57.4 & 32.6 & 43.2 \\
\hline 1.1 & 7.41 & 7.00 & 57.4 & 22.6 & 60.6 \\
\hline
\end{tabular}

Table 3. Results of laboratory tests of the coagulant-flocculant

\begin{tabular}{|c|c|c|c|c|c|c|c|c|}
\hline \multirow[b]{2}{*}{$\begin{array}{l}\text { Reagent } \\
\text { brand }\end{array}$} & \multirow[b]{2}{*}{$\begin{array}{l}\text { Dosage, } \\
\mathrm{mg} / \mathrm{dm}^{3}\end{array}$} & \multicolumn{7}{|c|}{ Concentration of pollutants in treated water, $\mathrm{mg} / \mathrm{dm}^{3}$} \\
\hline & & $\stackrel{\square}{2}$ & 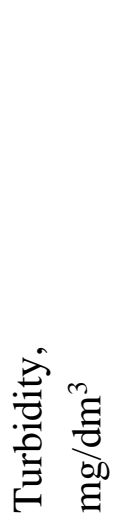 & 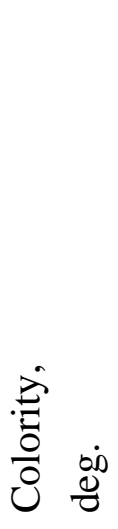 & 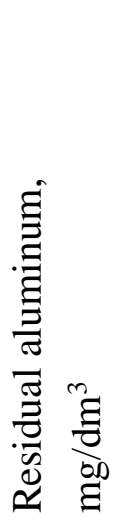 & 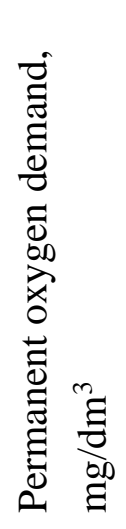 & 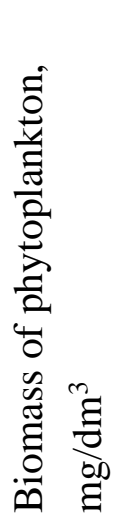 & 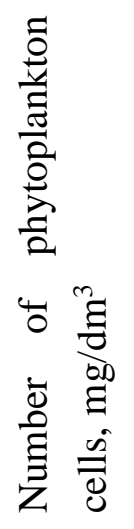 \\
\hline Polvak-68 & 5.0 & 8 & 1.97 & 26 & 0.31 & 5.8 & 0.52 & 2923 \\
\hline Polvak-68 & 7.0 & 8 & 1.39 & 25 & 0.29 & 5.0 & 0.63 & 4800 \\
\hline Polvak-68 & 10.0 & 8 & 0.87 & 17 & 0.27 & 3.9 & 0.21 & 2281 \\
\hline $\begin{array}{l}\text { Coagulant- } \\
\text { flocculant }\end{array}$ & 5.0 & 8 & 2.32 & 31 & 0.83 & 5.3 & 0.79 & 7079 \\
\hline $\begin{array}{l}\text { Coagulant- } \\
\text { flocculant }\end{array}$ & 7.0 & 7 & 1.91 & 29 & 1.06 & 4.7 & 0.50 & 4689 \\
\hline $\begin{array}{l}\text { Coagulant- } \\
\text { flocculant }\end{array}$ & 10.0 & 7 & 1.48 & 9 & 1.1 & 3.9 & 0.12 & 2969 \\
\hline Initial water & & 8 & 1.45 & 48 & - & 6.3 & 4.31 & 16407 \\
\hline
\end{tabular}




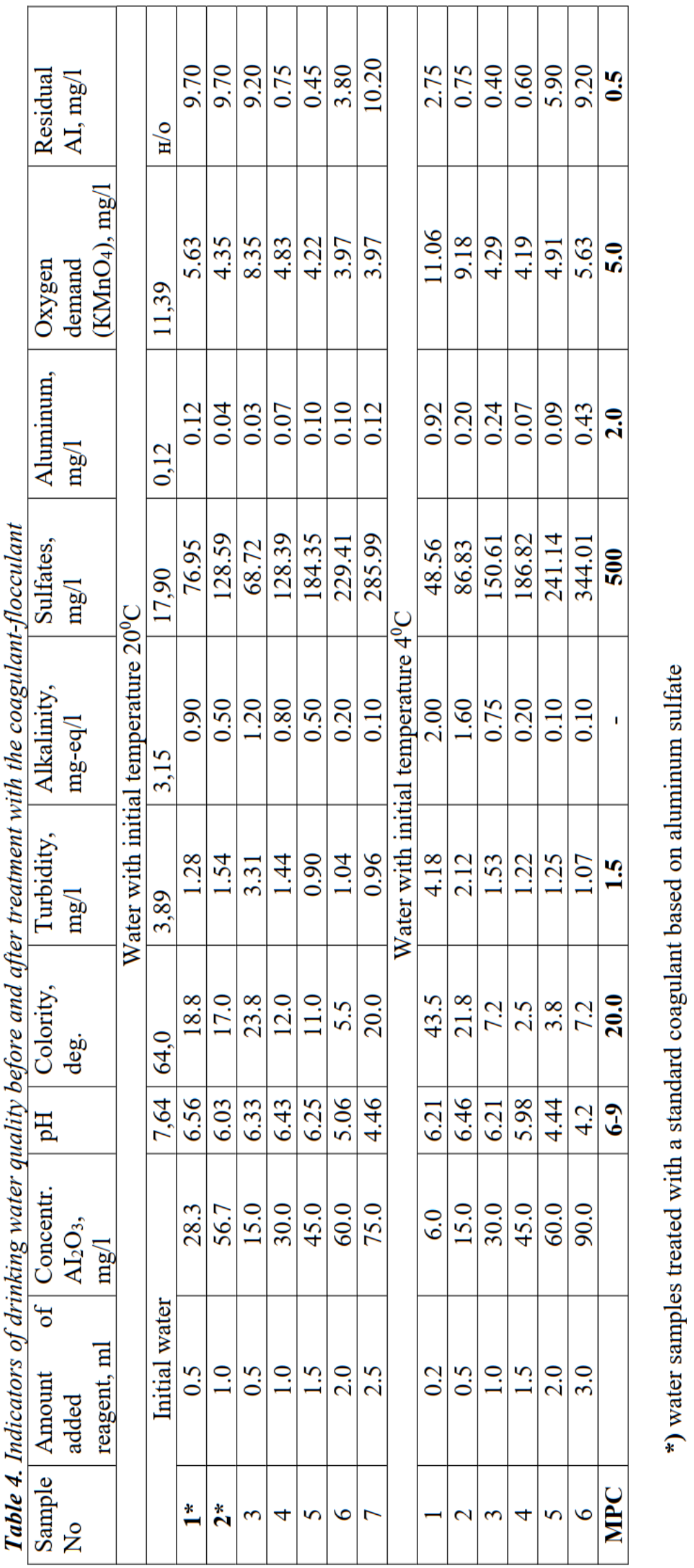


The research results are presented in Table 4, from which it follows that the value of all parameters characterizing the contamination of the source water are decreasing. The exception is sulfates, the concentration of which regularly increases, but still remains below the MPC. During the experiment, the optimal concentration of the coagulantflocculant was determined, which corresponds to $30-45 \mathrm{mg} / \mathrm{l}$ and allows all monitored water parameters not to exceed the standardized values of Sanitary Rules and Norms 10124RB 99.

\section{Conclusions}

1. As a result of the processing of nepheline concentrate with acidic production effluents, a highly efficient coagulantflocculant is obtained, which has a number of advantages over commercial products: a wider process temperature range of $6-30{ }^{\circ} \mathrm{C}$; a wider range of optimal media $\mathrm{pH}$ - 3.5-8.5; high strength and hydraulic size of the flakes; the ability to use for waters with a wider range of salt composition, the ability to eliminate harmful odors and tastes caused by the presence of hydrogen sulphide.

2. To achieve the necessary effect, a 1.5-2.0 times lower dose of the developed coagulant-flocculant is required comparing with coagulant based on pure aluminum sulfate.

3. The production of coagulantflocculant with low capital costs can be organized in the places of its use.

\section{References}

Kulskyi, L. A.; Strokach, P. P. Tekhnolohyia ochystky pryrodnikh vod; Kyiv: Vyshcha shk, 1982, 328 p.

Lainer, Yu. A. Kompleksnaia pererabotka aliumynyi-soderzhashcheho sirya kyslotnimy sposobamy; M.: Nauka, 1982, $208 \mathrm{p}$.

Veliaev, Yu. O.; Zakharov, V. Y.; Maiorov, D. V. Sovershenstvovanye tekhnolohyy poluchenyia

aliumokremnyevoho koahulianta-flokulianta na osnove nefelyna. Fyzyka y khymyia stekla, 2011, 37(5), 763-769.

Zapolskyi, A. K.; Baran, A. A. Koahulianty $y$ flokulianty $v$ protsessakh ochystky vody: Svoistva. Poluchenye. Prymenenye; M.: Khymyia, 1987, 208 p. 


\title{
КОАГУЛЯНТ-ФЛОКУЛЯНТ 3 ВТОРИННИХ РЕСУРСІВ ДЛЯ ОЧИЩЕННЯ ПРОМИСЛОВИХ І КОМУНАЛЬНИХ СТІЧНИХ ВОД
}

\author{
В. О. Шабловський ${ }^{1}$ А. В. Тучковська ${ }^{1}$ В. А. Рухля, О. Г. Пап \\ ${ }^{1}$ НДІ фізико-хімічних проблем БДУ, вул. Ленінградська 14, 220006, Мінськ, Білорусь, \\ email: shablovski@bsu.by
}

Практично на всіх об'єктах питного водопостачання та станиіях очищення стічних вод комунальних $i$ промислових підприємств Білорусі $\check{u}$ Украӥни застосовуються коагулянти $i$ флокулянти для інтенсифікації та підвищення ефективності процесів очищення, освітлення $i$ знебарвлення природних та стічних вод. Як коагулянти використовуються, в основному, солі алюмінію і феруму, а як флокулянти - активна кремнекислота, крохмаль, похідні иелюлози, поліакрілоамід тощо.

Сульфатнокислотна обробка алюмінійвмісної сировини дозволяе в ході одного процесу отримувати суміш активних речовин - солей алюмінію, феруму та активну $\mathrm{SiO}_{2}$. При цьому немає необхідності відокремлювати солі від завислих часток і колоїдної силікатної кислоти. Присутність в діючій речовині завислих дисперсних частинок, а також колоїдної силікатної кислоти і їі солей підсилює і прискорює коагуляиію. Одержаний розчин, поряд з алюмінієм сульфатом, містить також силікатну кислоту, яка в прочесі очищення води виконує роль флокулянта. Крім того, серед продуктів переробки є також ферум сульфат, в присутності якого досягається краший результат коагулювання.

Проведено промислові випробування коагулянту-флокулянту з метою очщщення стічних вод від нафтопродуктів. Результати випробувань показали, що ефективність коагулянту-флокулянту за умови незначного вмісту нафтопродуктів у стічних водах порівнянна з використовуваним на даний час алюмінісм сульфатом.

Ефективність розробленого коагулянту-флокулянту для підготовки питної води оцінювалася в порівняльних випробуваннях з коагулянтом «ПОЛВАК-68» в режимі пробної коагуляціі на лабораторному флокуляторі. Результати досліджень показали, що значення всіх параметрів, які характеризують забрудненість вихідної води, за умови використання експериментального коагулянту-флокулянту є значно нижчими в порівнянні зі звичайним продуктом.

Ключові слова: коагулянт, флокулянт, алюміній, стічна вода, питна вода 